\title{
Can Argumentation be Taught in School?*
}

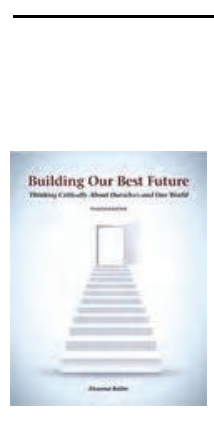

\section{Jeena Anne K}

Building Our Best Future: Thinking Critically About Ourselves and Our World

Deanna Kuhn Wesses Learning Pages: 212, 2017 ₹2659/-

ISBN-10: 0999064983 ISBN-13: 978-0999064986

Argumentation is considered an effective tool in science education to impart a sense of inquiry and scientific thinking skills. Can this be taught in school? Deanna Kuhn's book, Building our Best Future: Thinking Critically About Ourselves and Our World highlights that argumentation skills can be developed in a classroom setup, and gives an insight into how to achieve this.

Deanna Kuhn's book Building our Best Future: Thinking Critically About Ourselves and Our World is a practical handbook aimed at imparting the skill of argumentation among school children and thereby improving their abilities of scientific thinking and inquiry. It is intended as an effective teaching tool to equip teachers and students with the 21st-century skills which are to be incorporated into the pedagogy of science in today's schools.
Argumentation has been a topic of teaching interest for at least centuries before the common era. Most prominently, ancient Greek philosopher, Socrates is said to have practised argumentative dialogues with his students. The Socratic methods of questioning and dialogues with questions to find answers to bring about critical thinking are well-known [1]. As Nobel Laureate Amartya Sen has pointed out, the long history of the argumentative tradition in India and its contemporary relevance are being neglected in the Indian cultural discussions [2]. At present, argumentation is rarely practised in science classrooms in India, since science teachers are busy getting through the syllabus, and because they are not trained to handle argumentative dialogues with students.

The publication of Next Generation Science Standards, in the United States, collaboratively by the National Science Teachers Association, the American Association for the Advancement of Science, and the National Research Council, has raised the importance of science education from content knowledge acquisition to scientific inquiry and development of scientific thinking. The importance of critical thinking and argumentation has become even more obvious in the current pandemic stricken world. As Covid-19 is killing millions of people worldwide, scientific knowledge about the virus, how it attacks the human body, and how to control the virus is still in

${ }^{*}$ Vol.26, No.1

DOI: https://doi.org/10.1007/s12045-020-1110-z 
the making. Science education needs to equip school children to develop a flexible and critical approach to deal with a rapidly changing world.

Science is often considered and taught as the storehouse of unchallenged knowledge dealing with facts, theories, and scientific laws. However, many theories have been refuted years after they were proposed, and new theories have been corroborated. It was Karl Popper who proposed the idea of 'falsifiability'. He stressed on considering scientific findings critically and the chance of falsifying them [3]. According to Jiménez-Aleixandre and Erduran's Argumentation in Science Education [4], the three main types of learning goals of science curriculum are: (1) developing students' knowledge and skills on nature of science, (2) developing citizenship on socio-scientific issues, and (3) developing higher-order thinking skills. The pedagogy of argumentation is the latest of the various methods required to improve scientific thinking. As Kuhn et al., stress, the use of control of variable strategies to assess scientific thinking is not sufficient [5].

Argumentation studies in science education have increased at a rapid pace since the 1990s to the present day. Argumentation is the verbal exchanges based on reasons and pieces of evidence. The practice of argumentation in a suitable manner will improve the inquiry skills of a person. Therefore, exercising argumentation is important for science education and practice. Deanna Kuhn's book supports teachers to practice argumentation with the students and thus improve their thinking skills. There are two versions of the book, one for the students and the other for the teachers. The teachers' version has a part which has guidance for teachers to assess the argumentation made by the participants.

Part two of the book, which starts after the introduction, is divided into five different chapters, each one comprising a step to be followed while conducting an argumentation workshop. There are detailed explanations and tips to follow at each step. Right from choosing a position of argument at the beginning to the final showdown by the participants and writing a report about it, everything is explained in detail. Chapter six talks about what good evidence is. Simple information becomes evidence when it is identified as being able to support or weaken a specific claim. Each of the team members discusses each of the pieces of evidence and decides upon the strongest of all the evidence to be put as the top-most to support their claim. The group as a whole also discusses these at a later stage to get the approval of every member.

The third part of the book deals with the four different topics, namely those pertaining to personal future, community future, national future, and world future. Kuhn has developed altogether 44 topics that can be given to students for practice. An example of a topic pertaining to personal life is the question 'whether to concentrate on a subject a student is weak in or on a subject where the student is strong?' For a community issue, an example is 'homeschooling versus sending a child 
to school'. An example of a topic of national interest is "whether smoking is best reduced by educating people or by imposing a high tax on cigarette purchases?' A topic of importance to the future of the world is "whether nations should cooperate or compete in exploring outer space?' Each topic comes with a set of questions that are given to the students of both the teams. All these topics relate to social issues which the students are familiar with. Argumentation with these topics makes the students interested in the process so that later they will be able to deal with complex scientific topics with ease.

The final part of the book is for the teachers, enabling them to assess the students' reports. The team who gets more points is declared the winner. This is based on how they have performed during the showdown, how the electronic dialogue exchanges were done, whether they were able to weaken the opposite team's argument, whether they were able to reach an effective hypothetical agreement between a disagreeing pair, and an evaluation of their final report.

Quoting from the book, "rich arguments and counterarguments cannot be done from a vacuum", which explains why the questions are given to the team members who are engaged in the argument. Both the team members are given an identical set of questions from which each team member selects a question. The questions and answers provided for each topic increase the students' confidence to argue for their stance. The participants have to decide which question's answer will help them to make their argument stronger, based on which they ask for the answers which they will use as evidence for their argument.

Evidence can be either supporting $(+\mathrm{M})$ or weakening (-M) one's own argument or supporting $(+\mathrm{O})$ or weakening $(-\mathrm{O})$ other's argument. Ignoring the opposing side is never considered as winning on one's argument. The teams would come to a stand in which they support their own views, at the same time support some of the other's views, and weaken some of the other's views.

The book gives teachers the freedom to use argumentation pedagogy in their class without looking for various reasons that are to be brought in for each of the topics. Though it looks like a simple book, much effort has gone into bringing in the various arguments and reasons supporting each opposing stance. The book clearly explains how argumentation can be conducted, and it makes the reader understand the difference between argumentation and the kind of high energy debate which is conducted to assess leadership skills. The book gives the scope for an introvert child to participate actively in argumentation using electronic gadgets or notepad exchanges to argue.

It is understood that the book is written after several years of study with the middle school children of three schools near Columbia University, which serves as a proof that the practice of argumentation under controlled conditions is possible. Argumentation is an advanced pedagogical approach crucial for the 
present time so that each child gets trained in adapting to the uncertain future better. Training to think critically is what is required. We can assume that if a student has been trained in a few of the topics, he/she can become wellversed in the skill of argumentation which is essential for the practice of scientific thinking. If teachers are trained to conduct this workshop during their training course, it would be beneficial to the field of science education.

In the literature available about the study of argumentation practices in the pedagogy of science, this book outlines practical guidelines and tips to conduct an argumentation workshop in the best possible way. A study conducted by Kuhn et al. in 2017- Can engaging in science practices promote deep understanding of them?'- has shown that the experimental group who were trained to use various strategies like multivariate analysis improved their skills when compared to the control group. The study seemed to have led to the writing of the present book with its guided instructions about how to conduct an argumentation workshop.

The topics discussed in the book are socially relevant ones. For developing good argumentation skills, these will be helpful. We can conclude that it is desirable to have a book with intricate, science-related topics which make the students think more deeply about different views of tackling a scientific problem. This can be accomplished if it is incorporated into the science curriculum based on the syllabus at each grade level. Teachers can also develop relevant topics of argumentation if they are given the training to develop those. This book could be prescribed as a textbook for science teacher training in argumentation.

\section{Suggested Reading}

[1] $H$ Delic and $S$ Bećirović, Socratic method as an approach to teaching, European Researcher, Vol.111, No.10, pp.511-517, 2016 DOI: 10.13187/er.2016.111.511.

[2] A Sen, The Argumentative Indian: Writings on Indian History, Culture, and Identity, New York: Penguin Books Ltd., Farrar, Straus and Giroux, 2005.

[3] K Popper, The Logic of Scientific Discovery, (2nd Ed.). London: Routledge, 2002.

[4] D Kuhn, T S Arvidsson, R Lesperance and R Corprew, Can engaging in science practices promote deep understanding of them?, Science Education, Vol.101, No.2, pp.232-250, 2017.

[5] M P J Aleixandre and S Erduran, (Eds.), Argumentation in Science Education: Perspectives From Classroom-based Research, Springer, 2007.

Jeena Anne K

Department of HSS

IIT Madras

Chennai - 600 036, Tamil Nadu. Email: jeenaannek@gmail.com 